\title{
Qualification and investigation of crimes motivated by jealousy, hatred, and enmity
}

\author{
Aleksandr Nikolayevich Varygin ${ }^{1 *}$, Irina Alekseevna Efremova $^{1}$, Aleksandr Borisovich \\ Smushkin $^{2}$, Yana Vadimovna Malinina ${ }^{1}$, and Anna Eduardovna Titovets ${ }^{1}$ \\ ${ }^{1}$ Saratov State Law Academy, Department of Prosecutor's Supervision and Criminology, Saratov, \\ Russia \\ ${ }^{2}$ Saratov State Law Academy, Department of Criminalistics, Saratov, Russia
}

\begin{abstract}
The article is devoted to a comprehensive study of the criminal law, criminological and criminalistic aspects of combating crimes motivated by hatred, jealousy, or enmity. The background of the study is high statistical indicators that reflect the wide prevalence of the considered motives for committing crimes. At the same time, the article, for the first time, conducts a comprehensive study that examines these crimes and countering them from various sides. The objective of the study is to analyze the current state and develop current recommendations for considering factors of jealousy, hatred, or enmity in the qualification of acts, the development of criminological and criminalistic measures to counteract these crimes, as well as criminalistic programs and algorithms for the investigation of a group of crimes committed on the grounds of hatred, jealousy, or enmity. The methodology is based on the universal dialectical cognitive method. Besides, the authors used specific scientific methods: comparative-legal, hermeneutical, and logical methods, which ensure compliance with the general principles of scientific knowledge. The study is based on a systematic approach. The research novelty is due to the authors' non-trivial approach, which combines the achievements of criminal law, criminology, and criminalistics and develops a single set of issues based on this symbiosis of knowledge. As a conclusion, it is noted that the specifics of the qualification of crimes motivated by jealousy, hatred, and enmity depend not only on the internal emotional state of the person committing them but also on the external conditions in which the subjective attitude of the perpetrator towards the committed act is formed. It is necessary to develop recommendations for practitioners containing rules for the qualification of crimes in the competition of criminal law norms, in which to provide answers to questions related to typical errors in the qualification of crimes and to offer an interpretation of the evaluation categories, the application of which causes the most significant difficulty in practice. The paper presents the algorithms of the two main investigation programs developed based on the selected investigative situations.
\end{abstract}

Keywords: crime motives, qualification errors, investigation program

* Corresponding author: van808@yandex.ru 


\section{Introduction}

The activity of any person is associated with a motivational orientation. A motive is a particular motivation that causes a person's determination to commit a socially dangerous act. In criminology and criminal law, there are different classifications of motives for crimes. The motives of jealousy, hatred, and enmity appear to be widespread and extremely specific, which allows combining the crimes committed on their basis into a single group and subject them to a comprehensive study from the perspective of criminology, criminal law, and criminalistics.

\section{Methods}

The work uses a set of traditional research methods. The methodology is based on the universal dialectical cognitive method. Besides, the authors used specific scientific methods: comparative-legal, logical methods, which ensure compliance with the general principles of scientific knowledge. It is also necessary to point out the hermeneutical method, which allows interpreting terms and concepts, revealing their main and hidden meaning.

\section{Results and discussion}

The motives of jealousy, hatred, and enmity, as a rule, are attributed to personal [1, pp. 5963] motives with a changeable anti-social content [2, p. 211], having a malign character [3, p. 495]. In general, the considered motives may be legitimate and socially approved, but they may change their content depending on the current negative conflict situation, which may be caused by the victim's illegal or immoral behavior. It is considered that "the main distinguishing feature of this category of the most dangerous crimes is physical (mental) violence against the victim or the threat of its use. The result of violent acts may be the infliction of death, bodily harm or mental harm, which, due to various legal grounds, may be qualified differently" $[4$, p. 6].

Dictionaries indicate that "jealousy is an affective state that presupposes the presence of a feeling of love and is based on the desire to possess the object of love" [5, p. 510]. Hatred is "a feeling of strong hostility, malice" [6, p. 406]. Enmity is "relations and actions imbued with hostility, hatred" [6, p. 106].

Their motivational orientation causes problems of qualification of the considered crimes. Thus, the extreme manifestation of the motive of jealousy may have an emotionally affected color, which does not allow for a sufficiently clear and correct qualification for murder, murder with particular cruelty, and affected murder [7, pp. 1-15] (some authors generally refer to pathological jealousy as a psychiatric disorder [8, pp. 723-729]). Qualification problems are associated with the differentiation of one type of murder from another due to the lack of analysis depth of its features. There are difficulties in understanding the evaluative circumstances that are the criminal-forming features of the primary and qualified elements of crimes (exceptional cruelty, general dangerous method, etc.). So, quite often, multiple stab wounds are characteristic of murders out of jealousy [9, pp. 502-507].

According to Clause 16 of the Resolution, murder must not be regarded as committed under the qualifying signs provided for in paragraphs "a," "d," "e" of Part 2 of Article 105 of the Criminal Code, as well as under circumstances that usually involve the idea of special cruelty (in particular, multiple injuries, murder in the presence of persons close to the victim), if it was committed in a state of sudden strong emotional excitement or when exceeding the limits of necessary defense [10]. When murdering with special cruelty, the perpetrator is aware that he causes the victim special torment and suffering in committing the murder, 
which, as a rule, is absent when murdering in an affective state. Possible qualification errors can be the following: "overqualification", "underqualification", erroneous qualification [11, p. 455]. The first type of error may indicate an incorrect qualification in favor of choosing a norm with aggravating circumstances, ignoring the rule of competition of norms with aggravating and mitigating circumstances. The second is an incorrect choice of the norm with extenuating circumstances when necessary to carry out the qualification according to the qualified type of crime components. The third involves the wrong choice of a privileged crime or qualified crime components in the absence of both mitigating and aggravating circumstances. For the correct qualification of the actions of a person in an affected murder, it is especially worth paying attention to the reasons aimed at the occurrence of an affected state: violence, bullying, or serious insult on the part of the victim or other illegal or immoral actions (inaction) of the victim, a long-term psychotraumatic situation that arose in connection with the systematic illegal or immoral behavior of the victim, as well as the presence of the affective state.

According to the US criminologist Larry Siegel, "in recent years, gays and lesbians, as well as vagrants, have become the most frequent victims of hate crimes in the United States" [12, pp. 67-82]. In the foreign scientific literature, such crimes are often characterized as committed out of hatred (hate crime) [13, pp. 179-201]. In criminal law theory, hate crimes are often associated with extremist crimes committed on the grounds of political, ideological, racial, national, or religious hatred or enmity or the grounds of hatred or enmity against a social group. Hate crimes are not limited to extremist acts; as a rule, these are various acts that by their nature have a violent motivational color, that is, their perpetrators, at the heart of their criminal behavior, have some negative attitudes imbued with hatred, envy, anger towards the victims. Foreign authors note that "hate crimes can range from genocidal-scale murders committed by a nation-state to verbal insults by a single subject" [14, pp. 64796482].

In crimes committed with the motive of hatred, there are identical problems associated with the qualification of the estimated criminal-forming features of the crimes "battery", "other violent acts", "disfigurement", "honor", "dignity", "cruel treatment", the motives of "racial, national, religious hatred and enmity", "social group", "extremism", "extremist activity", and others. There is an incorrect choice of criminal law norms, overstatement, or understatement of qualifications associated with violations of qualification rules in the competition of criminal law norms.

Peculiarities of investigation of the category of crimes under consideration are connected, first of all, with the need to establish a motive for the act. It should be borne in mind that the intent to commit criminal acts for these reasons can be both long and carefully "cherished" and suddenly appeared, provoked by the situation. Accordingly, with a sudden intention, the attacker, as a rule, does not think through the preparation and concealment of crimes in advance, which leaves a more obvious trace picture, expressed in both material and ideal traces.

Actions and questions aimed at establishing motives can be both direct in nature, expressed in investigative actions, operational search activities, and other actions and activities, and indirectly identify motives by identifying legal facts that may lead to the emergence of such motives or be their consequence: divorce, change of name, relocation, sale of registered movable or immovable property. The latter circumstances may be established by sending requests to the relevant registration authorities. The importance of a proper investigation of the case circumstances and distinguishing from false accusations has been repeatedly emphasized by foreign authors [15, pp. 225-249].

It is possible to note the probability of two investigative situations: on the one hand, the person who committed the crime is known and gives truthful testimony; on the other hand, 
there is a situation when the person refuses to give truthful testimony, and there is no direct evidence of his or her guilt at the initial stage of the investigation [16, p. 43; 17, p. 20].

Taking into account these situations, the following investigation programs can be proposed:

In a situation of "Confession", the main task will be to fix the evidentiary information and clarify it. The following algorithm of actions is recommended: inspection of the scene of the incident; Interrogation of the victim and the suspect; Verification of testimony on the spot; Interrogation of witnesses; Other investigative actions aimed at clarifying the testimony and collecting other evidentiary information.

In the situation of "Refusal to testify", the task will be to change the suspect's position and prove his or her guilt. The following algorithm of actions is recommended: Inspection of the scene; Interrogation of the suspect; Search and interrogation of witnesses-eyewitnesses; Search and interrogation of witnesses who can clarify the specifics of the conflict between the victim and the suspect (relatives, neighbors, colleagues); Confrontations with the suspect; Searches at the place of residence and work of the suspect; Necessary examinations; Reinterrogation of the suspect.

\section{Conclusion}

Based on the above, it should be noted that the specifics of the qualification of crimes motivated by jealousy, hatred, and enmity depend not only on the internal emotional state of the person committing them but also on the external conditions in which the subjective attitude of the perpetrator towards the committed act is formed. Crimes motivated by hatred and enmity should not be limited only to extremist orientation crimes since they involve some negative attitudes formed by the perpetrator, characterized by hatred, envy, and anger towards the victims of crimes. Problems of qualification of crimes motivated by jealousy, hatred, and enmity, as a rule, are associated with various qualification errors and violations of the rules of qualification in the competition of criminal law norms. Therefore, it is necessary to develop recommendations for practitioners containing rules for the qualification of crimes in the competition of criminal law norms, in which to provide answers to questions related to typical errors in the qualification of crimes and to offer an interpretation of the evaluation categories, the application of which causes the greatest difficulty in practice.

The investigation of crimes committed based on hatred, jealousy, or enmity is recommended to be carried out according to one of the proposed programs designed in accordance with the situations of confession or refusal to testify.

\section{References}

1. B.V. Kharazishvili, Voprosy motiva povedeniya prestupnika v sovetskom prave [Questions of the motive of criminal behavior in Soviet law] (Tsodna, Tbilisi, 1963)

2. R.A. Galiakbarov (ed.), Ugolovnoe pravo Rossiiskoi Federatsii [Criminal law of the Russian Federation] (Saratov State Law Academy, Saratov, 1995)

3. A.I. Korobeev (ed.), Polnyi kurs ugolovnogo prava: v 5 t. T. 1: Prestuplenie i nakazanie [Complete course of criminal law: in 5 vols. Vol. 1: Crime and punishment] (Publishing house of R. Arslanov "Law Center Press", Saint Petersburg, 2008)

4. V.N. Kudryavtsev, A.V. Naumov (eds.), Nasilstvennaya prestupnost [Violent crime] (Spark, Moscow, 1997) 
5. Entsiklopedicheskii slovar po psikhologii i pedagogike [Encyclopedia of Psychology and Pedagogy]. Accessed on: December 8, 2020. [Online]. Available: https://psychology_pedagogy.academic.ru/14721/

6. S.I. Ozhegov, Tolkovyi slovar [Explanatory dictionary] (Russkii yazyk, Moscow, 1990). Accessed on: December 8, 2020. [Online]. Available: https://dic.academic.ru/dic.nsf/ogegova/124346

7. G. Serran, P. Firestone, Aggress. Violent Behav. 9(1), 1-15 (2004). https://doi.org/10.1016/S1359-1789(02)00107-6

8. N. Brémaud, Annales Médico-psychologiques, revue psychiatrique 174(9), 723-729 (2016). https://doi.org/10.1016/j.amp.2015.04.019

9. N. Radojević, B. Radnić, S. Petković, M. Miljen, I. Čurović, D. Čukić, M. Šoć, S. Savić, J. Forensic Leg. Med. 20(5), 502-507 (2013). https://doi.org/10.1016/j.jflm.2013.03.005

10. Postanovlenie Plenuma Verkhovnogo suda Rossiiskoi Federatsii No. 1 ot 27 yanvarya 1999 g. "O sudebnoi praktike po delam ob ubiistve" [Resolution of the Plenum of the Supreme Court of the Russian Federation No. 1 "On judicial practice in murder cases"] (1999, January 27)

11. A.N. Popov, Ubiistva pri otyagchayushchikh obstoyatelstvakh [Murder under aggravating circumstances] (Yuridicheskii tsentr Press, Saint Petersburg, 2003)

12. L.J. Siegel, Criminology (Wadsworth Publishing, Belmont, 2011)

13. K. Benier, Int. Rev. Vict. 23(2), 179-201 (2017). https://doi.org/10.1177/0269758017693087

14. E.M. Beck, Hate crimes, in N.J. Smelser and P.B. Baltes (eds.), International Encyclopedia of the Social \& Behavioral Sciences, 6479-6482 (Pergamon, Amsterdam, 2001). https://doi.org/10.1016/B0-08-043076-7/00374-0

15. B.E. Turvey, Chapter 10 - Hate crimes: misunderstanding, misapplication, and false reports, in B.E. Turvey, J.O. Savino, and A.C. Mares, False Allegations, 225249 (Academic Press, London-San Diego, 2018). https://doi.org/10.1016/B978-012-801250-5.00010-0.

16. N.K. Korovin, A.T. Pershina, E.S. Kazarezova, Znachenie kriminalisticheskoi kharakteristiki pri rassledovanii ubiistva na pochve revnosti [The significance of forensic characteristics in the investigation of a murder motivated by jealousy], in Sistema pravotvorchestva na mezhdunarodnom i federalnom urovne. Sbornik statei Mezhdunarodnoi nauchno-prakticheskoi konferentsii [The system of law-making at the international and federal level. Collection of articles of the International Scientific and Practical Conference] (Aeterna, Ufa, 2020)

17. V. Ruggiero, Political violence and crime, in Oxford Research Encyclopedia of Criminology and Criminal Justice (Oxford University Press, New York, 2017). https://doi.org/10.1093/acrefore/9780190264079.013.371 